\title{
Distal Bile Duct Cancer pTis TNM Finding v8
}

National Cancer Institute

\section{Source}

National Cancer Institute. Distal Bile Duct Cancer pT is TNM Finding v8. NCI Thesaurus.

Code C134799.

Distal bile duct cancer with a finding of carcinoma in situ/high-grade dysplasia. (from AJCC 8th Ed.) 